\title{
Physiological and Molecular Responses to Acid Rain Stress in Plants and the Impact of Melatonin, Glutathione and Silicon in the Amendment of Plant Acid Rain Stress
}

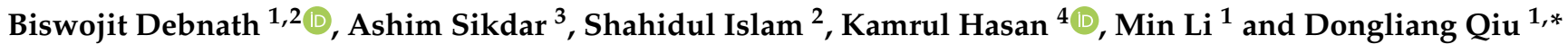 \\ 1 College of Horticulture, Fujian Agriculture and Forestry University, Fuzhou 350002, China; \\ biswo26765@yahoo.com (B.D.); liminzyl@sina.com (M.L.) \\ 2 Department of Horticulture, Sylhet Agricultural University, Sylhet 3100, Bangladesh; shahidul.hrt@sau.ac.bd \\ 3 Department of Agroforestry and Environmental Science, Sylhet Agricultural University, \\ Sylhet 3100, Bangladesh; ashim.aes@sau.ac.bd \\ 4 Department of Agricultural Chemistry, Sylhet Agricultural University, Sylhet 3100, Bangladesh; \\ hasanmk.agrichem@sau.ac.bd \\ * Correspondence: qiudl1970@fafu.edu.cn; Tel.: +86-13605948966
}

Citation: Debnath, B.; Sikdar, A.; Islam, S.; Hasan, K.; Li, M.; Qiu, D. Physiological and Molecular Responses to Acid Rain Stress in Plants and the Impact of Melatonin, Glutathione and Silicon in the Amendment of Plant Acid Rain Stress. Molecules 2021, 26, 862. https:// doi.org/10.3390/molecules26040862

Academic Editor: Dun-Xian Tan

Received: 6 January 2021

Accepted: 3 February 2021

Published: 6 February 2021

Publisher's Note: MDPI stays neutral with regard to jurisdictional claims in published maps and institutional affiliations.

Copyright: (c) 2021 by the authors. Licensee MDPI, Basel, Switzerland. This article is an open access article distributed under the terms and conditions of the Creative Commons Attribution (CC BY) license (https:/ / creativecommons.org/licenses/by/ $4.0 /)$.

\begin{abstract}
Air pollution has been a long-term problem, especially in urban areas, that eventually accelerates the formation of acid rain (AR), but recently it has emerged as a serious environmental issue worldwide owing to industrial and economic growth, and it is also considered a major abiotic stress to agriculture. Evidence showed that AR exerts harmful effects in plants, especially on growth, photosynthetic activities, antioxidant activities and molecular changes. Effectiveness of several bio-regulators has been tested so far to arbitrate various physiological, biochemical and molecular processes in plants under different diverse sorts of environmental stresses. In the current review, we showed that silicon (tetravalent metalloid and semi-conductor), glutathione (free thiol tripeptide) and melatonin (an indoleamine low molecular weight molecule) act as influential growth regulators, bio-stimulators and antioxidants, which improve plant growth potential, photosynthesis spontaneity, redox-balance and the antioxidant defense system through quenching of reactive oxygen species (ROS) directly and/or indirectly under AR stress conditions. However, earlier research findings, together with current progresses, would facilitate the future research advancements as well as the adoption of new approaches in attenuating the consequence of AR stress on crops, and might have prospective repercussions in escalating crop farming where AR is a restraining factor.
\end{abstract}

Keywords: acid rain; oxidative stress; antioxidant activity; silicon; glutathione; melatonin

\section{Introduction}

Societies have been using numerous natural means for their existence since the beginning of civilization. By using many of the earth's energy sources, people have made their lives easier. Contrarily, it has created pollution due to the released hazardous materials to the environment. Fossil fuel combustion from vehicles, industrial flourish and urbanization have increased the concentration of fumy and particulate impurities in the atmosphere, which causes air pollution [1]. Acid rain (AR) occurs due to intensive air pollution and it has become a common phenomenon worldwide, especially in Europe, East Asia and North America [2]. In China, AR has been documented as one of the major environmental pollution factors in recent years owing to the increasing commercial development [3,4]. The dissemination of AR was found to be increased in China since the 1970s and the occurrence of AR has predominantly been reported in Southern China. It was reported that only 11 provinces of South China experienced the loss of ecological benefits of more than US $\$ 2.4$ billion annually because of AR [5]. Therefore, the soil of a vast area in these parts has been found to be acidified and thereby major ecosystems are also in a vulnerable condition [4]. 
Robert Angus Smith was a pharmacist of Manchester, England, who observed high levels of acidity in rain water over industrial zones of England in the year of 1852 and discovered the phenomenon of AR [6]. In contrast, he observed lower acidity levels in rain water of slightly polluted areas, particularly near the coast [7]. Until the 1950s, his work was not able to arrest public attention. But, when biologists reported a drastic drop in the fish population of the southern Norway lakes as well as harmful effects on vegetation due to acidic rain water, scientists began to focus on the details of AR, like the way of its formation, nature and possible intensity of occurrence, and its impact on the earth [7].

Currently, AR is considered as a potential threat to the agriculture sector. Scientists piloted their researches through simulated acid rains (SAR) that may change the growth, development, physiological and molecular activities of plants, as well as a decline in the output [8]. AR impedes the basic plant growth indicators like plant height, leaf number, diameter of stem and shoot and root fresh biomass, implying that SAR stress in plants causes reduced plant growth and development [9-11]. In addition, AR hampers the photosynthetic activity of plants and thus, decreases the photosynthetic rate. Besides, the level of alteration in plant photosynthetic activities because of AR condition varied among plant species and with the level of stress $[12,13]$. Basically, AR deposition affects the ultrastructure of chloroplast and leaf plasma membrane, which result in lower photosynthetic activity and degradation of chlorophyll [14]. Ultimately, AR stress causes the accumulation of reactive oxygen species (ROS) and melondialdehyde (MDA) contents in plant cells $[8,12,13]$. It was observed in different crops that the antioxidant defense system was strengthened in response to moderate AR stress conditions to scavenge ROS and reduce oxidative injury, but the ROS detoxifying ability decline in severe stress conditions might be due to the changes in metabolic status or their biosynthesis [8]. Furthermore, AR causes the alternation in the differentially expressed genes and transcriptional factors [15]. In the past decades, the mechanisms of plant response to AR stress were very briefly elucidated in tomato and research on AR stress mitigation processes were not done in tomato.

It has been studied that different bioactive compounds such as silicon, glutathione and melatonin can improve the abiotic stress tolerance, including AR stress in plants [16-18]. Silicon is the second richest element in the soil and acts as a useful component for higher plants [19]. It has been established that silicon can improve plant tolerance against different abiotic stresses including salinity, drought, metal toxicity, etc., and biotic stresses including pathogens and insects [19-23].

Similarly, glutathione is considered one of the major non-protein thiol bioactive watersoluble compounds (Phytochelatin) in plant cells and plays diverse biochemical roles in plants to adapt to abiotic stresses through ROS scavenging directly and/or activating different antioxidant compounds [24,25]. The phytochelatin also plays a vital role in protecting cellular functions through different mechanisms and metal/metalloid homeostasis by performing their chelation and/or detoxification [26]. In addition, glutathione plays a vital role in growth, development, photosynthetic activity, expression of differential genes and activation of protein by means of its diverse properties under abiotic stress conditions $[17,24,25,27]$.

On the other hand, melatonin ( $N$-acetyl-5-methoxytryptamine) is a low molecular weight natural molecule which is present in living organisms, spreading from mammals to bacteria [28]. It is well-reported that melatonin has important positive functions in animal and plant physiology as well as in various human processes [29-32]. The pleiotropic biological activities of melatonin in living organisms are arbitrated by membrane receptors and nuclear receptors [33,34]. Moreover, melatonin receptors work independently [35], and their bioactive metabolites affect the interactions of melatonin with ROS [36].

As it is amphiphilic in nature, melatonin can easily infiltrate the cell membrane and dispense to the cytosol, the nucleus and mitochondria [37]. In fact, melatonin plays a crucial role in the non-receptor-mediated activities such as quenching ROS, and enhancing antioxidant capacity, protecting living cells from oxidative injury [38-40]. Consequently, the formation and absorption of ROS are the elementary processes related to cellular 
biology and physiopathology. Thereby, it is anticipated that the principal role of melatonin in living organisms is to strengthen the antioxidant system and act as a front-line defense against any adverse environment [41].

In the current review, emphasis has been given on the systematic and deep exploration of the recent advances in research of AR stress mitigation in plants by the supplementation of different bioactive compounds like silicon, glutathione and melatonin. Notably, the mechanisms of bioactive compound-mediated AR stress tolerance in plants have gradually been exposed. Therefore, the effects of AR on the photosynthesis potential, metabolic mechanism of ROS accumulation and mechanism of AR stress tolerance-related gene expression in plants have been summarized. However, based on the previous and current research outputs, the detailed impact of exogenous silicon, glutathione and melatonin on plant metabolic processes underlying the AR stress tolerance mechanism has been elucidated, which would be perceptive and supportive for the future research in AR stress amelioration using the studied bioactive compounds as well as might pave the way for attempting new compounds in different plants.

\section{Impacts of Acid Rain on the Photosynthesis Potential in Plants}

Photosynthesis is a fundamental physio-morphological process to sustain plant life activities, including growth and development, and this process helps in the synthesis of organic composites by the usage of light energy in plants [17,42]. Photosynthetic pigments like chlorophyll and carotenoids are vital for photosynthesis, which is essential for the growth and development of plants, and these are the penetrating signs to observe the harmful impacts of different environmental hazards on germination, seedling growth, leaf structure, health and function [43-45]. Chlorophyll converts carbon-dioxide and water into biochemical energy like carbohydrates and oxygen by using light energy [46]. Basically, the chlorophyll content in plants indicates the effectiveness of photosynthesis, and the increased ROS accumulation in plants under environmental stress conditions triggers a significant decline of chlorophyll content in plant leaves because of its fragile nature [47]. Contrarily, carotenoids act as a safeguard for the photosynthetic apparatus by quenching ROS through the xanthophyll cycle under biotic and abiotic stress conditions [48].

Currently, it has been observed in several experiments that chlorophyll concentration as well as photosynthesis in tomato plant are severely affected by environmental stresses, including high temperature, low temperature, salinity, alkalinity, drought, metal toxicity and others [49-54]. AR is also considered a major abiotic hazard due to its hostile influence on bio-energetic advancement of photosynthesis [55,56]. Previous research reported that the chlorophyll content significantly declined due to AR in tomatoes [57] and the trend of declination was associated with the extent of AR stress and plant species [58]. The authors observed that the lessening of chlorophyll a and chlorophyll b content was higher at $\mathrm{pH} 2.5$ of AR compared to $\mathrm{pH} 3.5$ of AR in leaves of two different types of tomato cultivar, namely Micro-Tom as a determinate type and Red Rain as an indeterminate type. Moreover, the degradation of chlorophyll concentration is a distinctive indicator of leaf senescence, which causes yellowing of leaves in tomato plant [58]. It has been stated that chlorophyll loss is accompanied with the upregulation of chlorophyll degradation genes, for example SGR1 and PAO $[59,60]$. On the other hand, carotenoid contents in tomato leaves decrease markedly under AR stress and the decrease level depends on pH level of AR water [58]. The results indicate that AR, having a higher acidity level, causes a higher amount of light absorbance, which releases maximum heat, resulting in lower usage of light energy and damage to photosynthesis pigments [44]. Therefore, the growth, development and survival of plants depend on functional photosynthesis apparatus, which are fundamentally hampered by AR stress.

Chlorophyll fluorescence is certainly affected by abiotic stresses and commonly used as a sensitive indicator to observe the photosynthetic status of plants [61]. The measurement of chlorophyll fluorescence is considered as a rapid, prominent and reliable technique to evaluate photosynthetic activities in any stressed plant $[43,62]$. The measurements of the 
primary photosystem II (PSII) are observed as the value of the Fo (minimal fluorescence level when plastoquinone electron acceptor pool, Qa, is fully oxidized) and the ratio of Fv and Fm (maximum quantum efficiency of photosystem-II), which are primarily sensitive to environmental stress conditions $[10,58]$. AR in tomato seedlings increases Fo value and decreases Fv/Fm ratio, which indicate that AR stress can knock down the photochemical efficiency of PSII photosynthetic apparatus [57,58]. Similarly, AR decreased the efficiency of photosystem II in different crops, like maize and amaranth seedlings [43]. The possible reason was that the high acidity level of $A R$ water can damage the photosynthetic pigments and injure the assimilation tissues.

In addition, photosynthetic pigments in plants may be degraded under AR stress because of the disruption of chloroplasts and lowering of water potential in the cells, which further lead to closure of stomata and lower $\mathrm{CO}_{2}$ assimilation, subsequently resulting in introverted cell division $[17,63]$. In Figure 1, the ultrastructure of a mesophyll cell and chloroplast in the midrib of tomato leaves, observed by transmission electron microscopy (TEM), showed asymmetrical size and shape of chloroplasts, starch grana and a recognizable cell wall without the perfect shape of a cell under the AR stress condition [57]. Likewise, the distorted lamellar structure of chloroplasts and the dwindling chloroplasts collapsed with imperfect thylakoid structure were found in tomato leaf ultrastructure after AR treatment [57]. The perfect starch grana, thylakoids and lamellar structure in leaves directed to development of photosynthetic pigments and enhancement of light energy absorptions and transformation of light energy capacity [16]. AR stress condition with lower $\mathrm{pH}$ level disrupts the chloroplast structure and thylakoids, and sometimes the starch grana disappears, which might block the photosynthetic transport in leaves and ultimately inhibits photosynthesis in plants $[9,16]$.
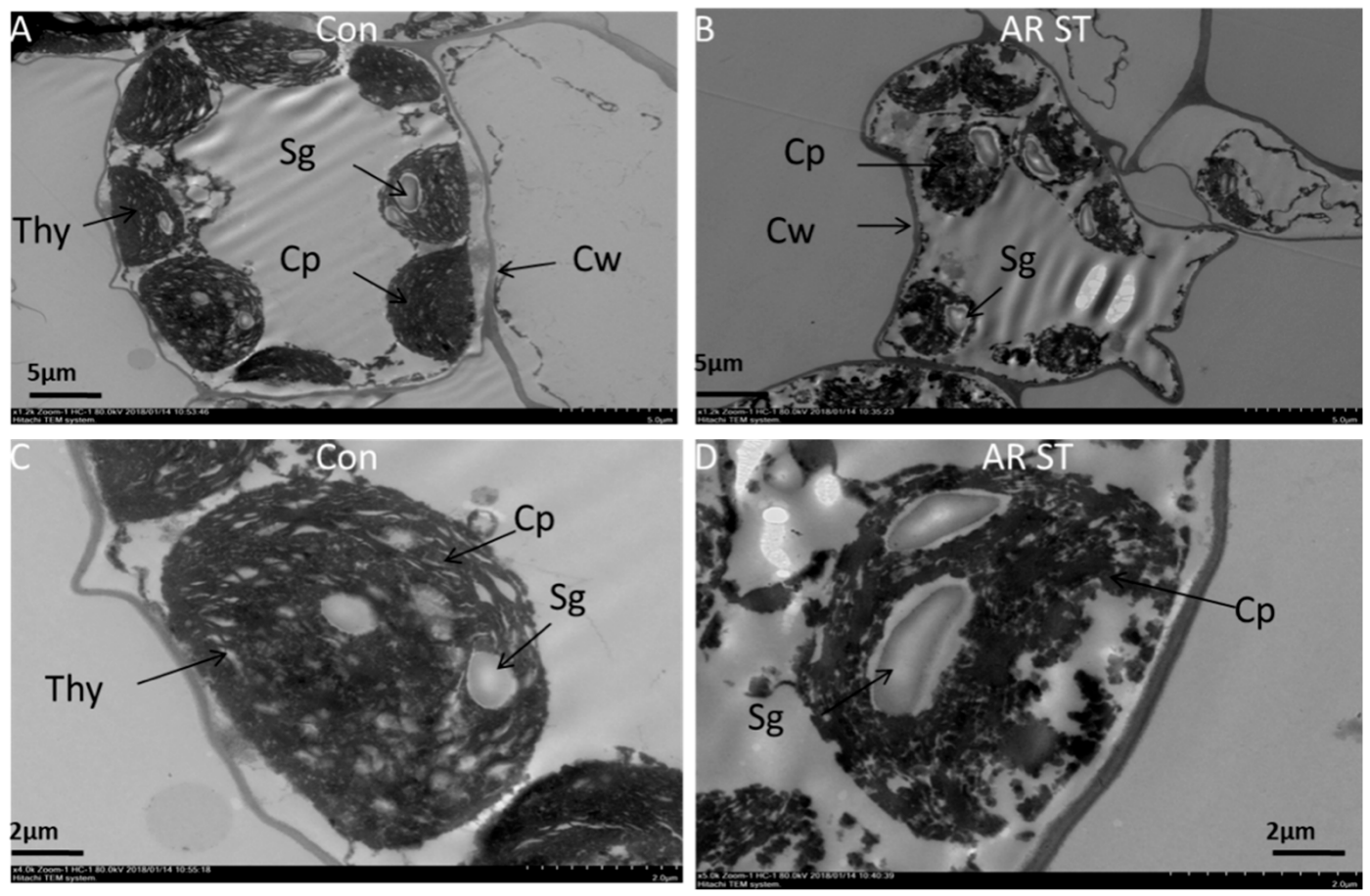

Figure 1. Ultra-structures of mesophyll cells of the middle part of midrib of the tomato leaf through transmission electron microscopy (TEM). (A,B) figures show TEM structure of whole leaf mesophyll cell of control and acid rain (AR)-stressed (AR-ST) tomato leaf, respectively. (C,D) figures show a relatively low magnified view of mesophyll cell of control (Con) and AR-stressed (AR-ST) tomato leaf, respectively. CP, Chloroplast; CW, Cell wall; Thy, Thylakoids; Sg, Starch grana [57]. 


\section{Reactive Oxygen Species (ROS) Stress and Its Metabolic Mechanism}

Plants are immobile in nature, but when any plant faces any adverse environmental condition, they can transform their own physiological status to adapt to an unfavorable environment. In any plant exposed to a harsh growing condition, a rapid and significant disparity ascends within the plant cells to survive. Plants in any stress condition result in the production of huge extents of ROS in mitochondria, chloroplasts and peroxisomes [64]. ROS accumulation can cause abnormalities to these organelles [65], by oxidizing proteins, lipids and nucleic acids [66]. Hydrogen peroxide $\left(\mathrm{H}_{2} \mathrm{O}_{2}\right)$ acts as one of the utmost active, deadly and damaging ROS. Hydrogen peroxide performs dual role in plants. $\mathrm{H}_{2} \mathrm{O}_{2}$ at low concentrations acts as a signaling molecule, boosting tolerance to any stresses, whereas, at high concentrations, it leads to plant cell death due to oxidative damage [67]. It has been reported that a high concentration of $\mathrm{H}_{2} \mathrm{O}_{2}$ in the plant cells often causes oxidative stress, which finally breaks the antioxidant level, resulting in leaf senescence and sometimes death $[44,61]$. It has universally been stated that AR with high concentration of acidity markedly accelerates the accumulation of ROS by generating more $\mathrm{H}_{2} \mathrm{O}_{2}$ [8,17]. Similarly, AR stress causes enhanced production of $\mathrm{H}_{2} \mathrm{O}_{2}$ in leaves of plants, which is linked to the acidity extent of AR water [57,58].

On the other hand, due to accumulation of excess ROS and resultant redox imbalance, lipids peroxidation, the damaging process occurs inevitably in every living cell. Sometimes, membrane damage is considered as a sole index to evaluate the extent of lipid destruction under various environmental stresses. It was established that during lipid peroxidation, products are formed from polyunsaturated precursors, including small hydrocarbon fragments like ketones and MDA [68]. MDA acts as a distinctive constituent of reactive carbonyl species produced as a result of lipid peroxidation, and it is considered as a bio-indicator of free radical-catalyzed peroxidation [69,70]. This MDA forms colored thiobarbituric acid-reactive substances (TBARS) by reacting with thiobarbituric acid (TBA) [71]. Lipid peroxidation (MDA) occurs in both cellular and organelle membranes when the threshold limit of ROS is exceeded. As a result, the produced MDA not only exerts a direct effect on normal cellular function, but also aggravates the oxidative injury through the function of lipid-derived radicals [72]. AR stress can encourage membrane injury, and increase permeability of membrane and the buildup of free radicals in plants [61]. Several experiments have been performed, observing the alteration of MDA concentration under AR stress conditions in leaves of different plants, including Arabidopsis [73], soybean [74], rice [75] and Horsfieldia hainanensis [76]. Likewise, it was reported that tomato seedlings exposed to AR considerably increased the accumulation of MDA [57,58].

Therefore, diverse bio-regulators are stimulated in the amendment to the adverse environment to boost the predominant competences of bioremediation. Notably, plants activate their antioxidant defense system to save themselves from the injurious impacts of ROS in AR stress conditions, alike to other harsh environments [12,13]. In addition, both the enzymatic and non-enzymatic antioxidant compounds act as an antioxidant system to balance ROS and cell membrane stability in stress conditions [77]. The superoxide dismutase (SOD) is plentiful in most of the aerobic organisms and all subcellular compartments, and is considered as a very effective intracellular enzymatic antioxidant which is susceptible to ROS-intervened oxidative stress in different environmental stress [44,61]. Tomato plant exposed to AR stress changes the activity of SOD. Moderate AR with $\mathrm{pH} 3.5$ or more may increase the activity of SOD in tomato seedlings, but severe AR conditions having $\mathrm{pH} 2.5$ might break the SOD activity power in tomato plants $[57,58]$. Similarly, ascorbate peroxide (APx) is assumed to perform a crucial role in protecting cells in higher plants and other organisms through quenching ROS under adverse environments. APx is involved in ROS detoxification in water-water and ascorbate-glutathione cycles, and also in making use of ascorbate as the electron donor [78]. It was observed that the expression of APx changed markedly under AR stress conditions in leaves of tomato plants, where the rate of alteration differed with the acidity levels of AR water $[57,58]$. APx can be differentiated from peroxidase (POD) in plants in terms of variances in sequences and physiological activities. 
POD transforms to indole-3-acetic acid (IAA) and plays a role in lignin biosynthesis and in defense against different stresses via overriding hydrogen peroxide. Peroxidase desires aromatic electron donors, for example guaiacol and pyragallol, which typically oxidize ascorbate at about $1 \%$ the rate of guaiacol [79]. The peroxidase activity in plants noticeably depends on plant species and stress condition. Several researchers observed that POD activity in plants significantly increased with AR treatment compared to normal condition $[8,12]$. Similar to other plants, AR treatment increased POD activity in tomato plants, and the rate of POD activity enhancement depends on plant species and acidity level in AR water $[57,58]$. In addition, catalase (CAT) is tetrameric heme comprising antioxidant enzymes having the capacity to convert $\mathrm{H}_{2} \mathrm{O}_{2}$ into $\mathrm{H}_{2} \mathrm{O}$ and $\mathrm{O}_{2}$. CAT plays a vital role in detoxifying ROS under any abiotic stress conditions [68]. Like other antioxidant enzymes, CAT activity was also found to be increased in tomato seedlings under AR stress conditions depending on the species and level of $\mathrm{pH}$ in $\mathrm{AR}$ water $[57,58]$.

On the other hand, there are some important non-enzymatic enzymes, e.g., phenolic, flavonoid and proline, that act as ROS scavengers in plants under different environmental stress conditions. Those non-enzymatic antioxidants perform a significant role in the cell structure and function, maintaining the redox status of cells [80]. Like other abiotic stresses, AR stress in plants increases the accumulation of phenolic, flavonoid and proline, and these phenolic, flavonoid and proline help in indirect ROS scavenging, intracellular redoxhomeostasis rebuilding and advancement of cellular signaling [44,56,81]. It was observed that the non-enzymatic activity including phenolic, flavonoids and proline increased in tomato seedlings under AR stress $[57,58]$. But, it was also observed that these enzymatic and non-enzymatic activities could not compensate for the damages caused by severe AR stress in tomato plants [58]. From the above discussion, it can be summarized that enzymatic and non-enzymatic antioxidant activities might help in balancing ROS accumulation and detoxification in plants when the plants are exposed to mild AR stress conditions, but the detoxification capacity can be broken in severe AR stress conditions (Figure 2).

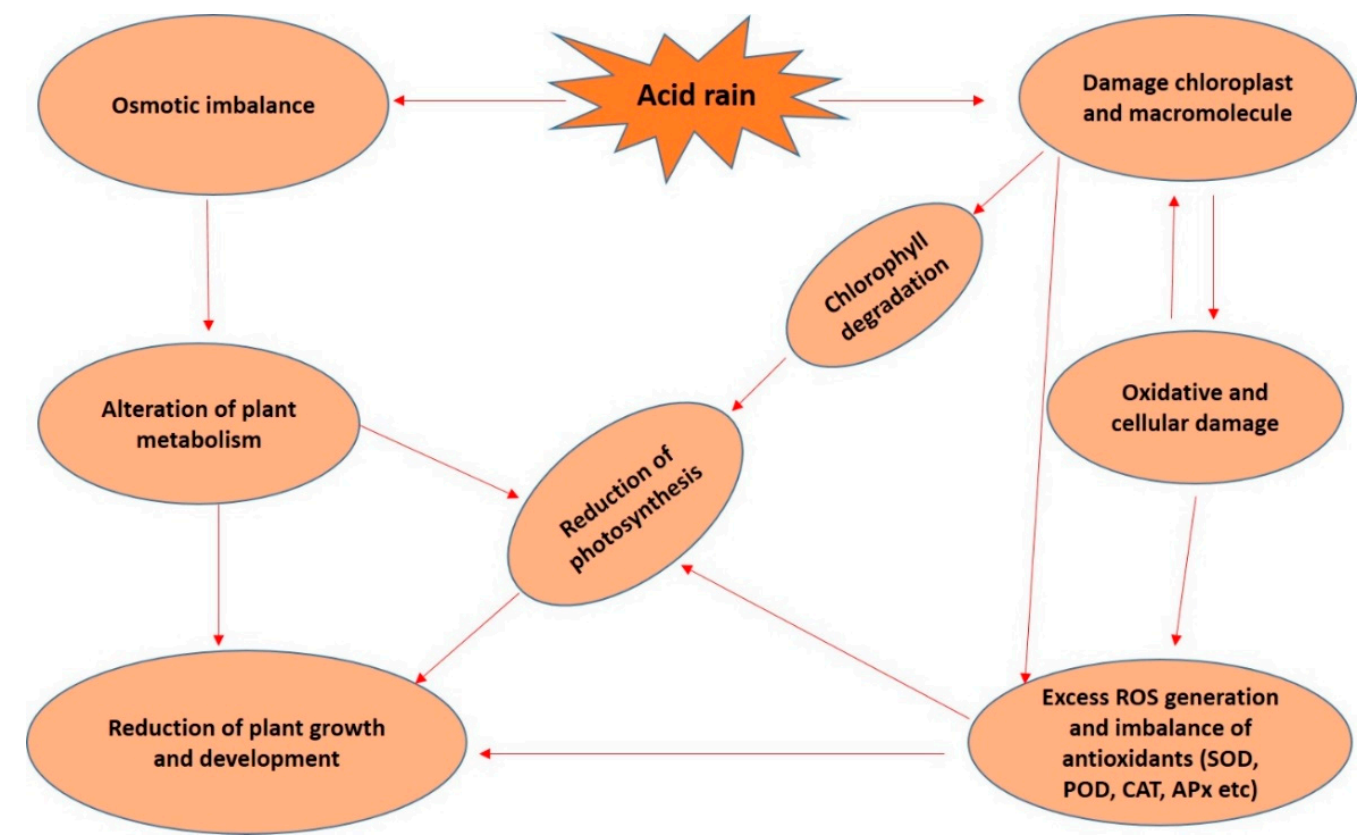

Figure 2. The action of acid rain stress on photosynthesis, antioxidant system and growth in plants. Here, ROS-reactive oxygen species, SOD—superoxide dismutase, $\mathrm{POD}$ - peroxide, CAT—catalase, APx—ascorbate peroxidase.

\section{Mechanism of Acid Rain in Related Gene Expression in Plants}

The physiological and biochemical activities, including photosynthesis, generation of ROS, enzymatic and non-enzymatic antioxidant defense, alternation of plant secondary 
metabolites and stress responsive transcriptional factors in plants, under any abiotic stress conditions, including acid rain stress, can be confirmed by their gene expression pattern [15,18,82-84]. It was observed that a series of genes are engaged in the photosynthesis system of Arabidopsis thaliana, for example, At2g01590 and At4g27880 genes are known as photosynthetic electron transport chain-related genes, and At2g34430, At2g05070, At3g08940, At3g27690, At1g15820, At5g54270 and At1g03130 are known as the PSI and PSII constituent protein-related genes that show suppression or expression of downregulation due to AR stress [15]. In contrast, it was observed that the expression of RuBP, known as ribulose-1,5-bis-phosphate, and RuBisCO, known as carboxylase/oxygenase, were evidently dropped in Arabidopsis thaliana by AR stress [85]. The proteomic study also stated that the expression of carbonic anhydrase gene transformed markedly, indicating that the photosynthesis is vulnerable to some extent against AR [85]. ROS formation in plant cells due to AR stress can be witnessed by the accumulation of superoxide anion $\left(\mathrm{O}^{-2}\right)$ and $\mathrm{H}_{2} \mathrm{O}_{2}$, which triggers membrane damage through producing MDA. Plants try to recover the ROS-induced membrane damage by altering their antioxidant components. Therefore, different enzymatic and non-enzymatic antioxidant activities in plants under environmental stress conditions can be well-observed by the expression pattern of their related genes, for example, CAT1 for catalase, Mn-SOD, Fe-SOD and Cu/Zn-SOD for superoxide dismutase, POD1 for peroxidase, APx genes for L-ascorbate peroxidase, GST genes for glutathione $\mathrm{S}$ transferase and AA genes for ascorbic acid were observed to be changed under AR condition [8,12,17]. Furthermore, in earlier studies, some genes were reported to be induced by AR stress conditions in plants, which were directly involved in the ROS-scavenging pathway, such as At1g08830 and At4g25100, documented as superoxide dismutase genes, At4g11600 and At2g25080, recognized as glutathione peroxidase genes, At3g49120, known as a class III peroxidase gene, At5g03630, identified as a monodehydroascorbate reductase gene, At4g35090, isolated as a peroxisomal catalase gene, and At5g16400, At1g07700 and At1g08570, accepted as thio-redoxins genes [15].

A transcriptome study in tomato seedlings showed that 182 differentially expressed genes (DEGs) were upregulated but 1046 DEGs were downregulated under AR stress condition [18]. Gene ontology (GO) analysis of this study showed that $28.86 \%$ of DEGs were involved in biological process, $46.34 \%$ of DEGs were involved in cellular process and $24.81 \%$ DEGs were involved in molecular function in AR-stressed tomato seedlings in comparison to controlled tomato seedlings. In addition, a significant number of DEGs, 174, were found to be associated with biosynthesis pathways of secondary metabolites, including phenylpropanoid, flavonoid, stilbenoid, diarylheptanoid and gingerol, phenylalanine metabolism, starch and sucrose metabolism, amino sugar and nucleotide sugar metabolism, cutin, suberine and wax biosynthesis, metabolic pathways, limonene and pinene degradation, ubiquinone and other terpenoid-quinone biosynthesis, flavone and flavonol biosynthesis, anthocyanin biosynthesis, brassinosteroid biosynthesis, zeatin biosynthesis, arginine and proline metabolism, cysteine and methionine metabolism and carotenoid biosynthesis with respect to AR stress versus control plants through KEGG (Kyoto Encyclopedia of Genes and Genomes) analysis, and among them, only 25 genes were upregulated and the other 149 genes were downregulated [18].

On the other hand, expression of transcriptional factor (TF) family genes is involved in different mechanisms in response to environmental stresses in plants. It has been well-established in several comparative transcriptome analyses that over $30 \mathrm{TF}$ family genes, including $M Y B, W R K Y, E R F$ and $b Z I P$, were found under different environmental stresses [86,87]. The TF genes like $M Y B, W R K Y, E R F$ and $b Z I P$ act as fundamental regulators in abiotic stress signal transduction as well as complex in biosynthesis of plant secondary metabolites in response to harsh environments [88-90]. Liu et al. [15] observed that AR treatment induced MYB transcription factor, zinc finger proteins, WRKY transcription factors and calcium signal pathway-related genes in plants. In another study, Debnath et al. [18] showed that 151 TF genes which were associated with 31 types of transcript factor family protein were expressed in comparison with control and AR-stressed 
tomato seedlings, and among the TF-allied DEGs, different stress responsive genes such as $E R F, M Y B, W R K Y, N A C, b H L H, T C P, G 2$-like and $C 2 H 2$ family protein-related genes were markedly expressed. These findings suggested that genes associated with biosynthesis of secondary metabolites and transcriptional factors are significantly induced by AR stress conditions in tomato plants.

\section{Impact of Silicon in Plants under Acid Rain Stress Conditions}

Silicon is well-known as a useful element which can improve the biotic and abiotic stress tolerance in plants [91]. The silicon content in plants varied in between cultivars and species plant growth stages [92]. It is well-established that silicon can advance the chlorophyll content and photosynthesis rate through adjusting oxidative damage in different environmental stresses, like high temperature, salinity, drought and heavy metal [93-98]. In addition, Ju et al. [16] observed that the application of exogenous silicon in plants improved the chloroplast ultrastructure, chlorophyll content and rate of photosynthesis, as well as plant growth under moderate to severe AR stress. The integration of silicon in plants under AR stress conditions can improve stomatal conductance and lessen the intercellular $\mathrm{CO}_{2}$ concentration, which results in the stimulation of photosynthesis and growth in plants [99]. AR stress tolerance in plants depends on the concentration of silicon and the level of $\mathrm{pH}$ in $\mathrm{AR}$ water [16]. Likewise, the application of silicon in tomato seedlings could increase the photosynthesis pigment, including chlorophyll and carotenoids, as well as improve the growth under abiotic and biotic stress conditions [100,101]. Moreover, the chlorophyll fluorescence parameters such as Fv / Fm rate (maximum photochemical efficiency of PSII), ETR (photosynthetic electron transport rate) and $\mathrm{q}_{\mathrm{p}}$ (photochemical quenching coefficient) were increased by silicon supplementation in tomato seedlings under stress conditions $[16,100]$. It was also observed that the application of silicon in tomato seedlings under stress conditions upregulated the expressions of photosynthesis-related genes such as PsbP, PsbQ, PsbW, Psb28, PetE and PetF [100]. Furthermore, silicon can alleviate stress in plants by increasing the activity of ROS-scavenging antioxidant compounds such as SOD, CAT, POD, phenylalanine ammonialyase (PAL) and polyphenol oxidase (PPO) in plants $[22,23,102]$. These results demonstrate that exogenous silicon might improve the AR stress tolerance by stimulating the physiological and biochemical activities in tomato plants.

\section{Effect of Glutathione in Plants under Acid Rain Stress}

Glutathione is a low molecular thiol tripeptide compound universally distributed in all the subcellular organelles of plants and plays a crucial role in life processes by removing cytotoxic hydro-peroxides and free radicals, maintaining the thiol level in proteins exchanging thiodusulfide and amino acid transportation across the cell membranes [24,103]. Glutathione has a remarkable role in plant growth, development and response to stresses [103]. It triggers cellular defense against ROS in plants under abiotic stress conditions due to its redox and nucleophilic properties [24,80]. The high concentration of glutathione in the cells regulates a buffering system to maintain redox-balance [104]. Glutathione can quench free radicals directly or by accompanying ascorbic acid in the ascorbate-glutathione cycle which helps in defending cell components from stress-induced oxidative damage [25]. It has been established that supplementation of glutathione improves the plants' tolerance to stress, such as tolerance in rice to salinity [105], tolerance in tomato to cadmium [104], tolerance in wheat to lead [24] and tolerance in fenugreek to AR [17].

The application of glutathione markedly improves different growth parameters such as plant height and fresh and dry biomass of root and shoot under AR stress through minimizing ROS accumulation and improving the activities of antioxidant enzymes that eventually reduce oxidative stress [17]. It has been reported that most of the plants could activate their antioxidant system up to a certain level against abiotic stress conditions [106,107]. However, the supplementation of glutathione in AR-stressed plants causes further intensification in the antioxidant activities, possibly owing to the signaling role of applied molecules, and this 
was confirmed through the transcript profiling of CAT, Mn-SOD, Fe-SOD and $\mathrm{Cu} / \mathrm{Zn}$-SOD genes [17]. In addition, glutathione-induced enhancement in abiotic stress tolerance in plants was closely associated with the upregulation of numerous transcriptional factors, including ERF (ethylene responsive transcriptional factor), MYB transcriptional factor and other stress response genes [104]. Therefore, it can be suggested that exogenous glutathione acts as an important bio-stimulator in avoiding oxidative damages by activating their defensive genes, which results in the improvement of stress tolerance in the plants against harsh environments $[17,24,104]$.

\section{Role of Melatonin in Plants under Acid Rain Stress}

Melatonin is naturally available in all types of plants and its biosynthesis leads to the significant mechanisms in plants for the survival against different stresses $[47,108,109]$. Melatonin directly contributes to the plant defense through scavenging free radicals and thus mitigates abiotic and biotic stresses [38,40]. Melatonin also indirectly enhances plant tolerance through recovering leaf ultrastructure, improving the photosynthesis system and regulating plant growth regulators [110]. In this context, exogenous melatonin showed amazing mechanisms to cope with the adverse environments by facilitating plant growth regulation, decelerating leaf senescence, improving photosynthesis and increasing ROS quenching antioxidant systems in plants [111,112]. However, melatonin-mediated physiological and molecular activities in plants prove that melatonin is an efficient molecule to stimulate plant growth, particularly where environmental stresses are the limiting factors for crop production.

Similarly, as observed in Reference [57], the foliar application of exogenous melatonin considerably increased antioxidant activities, reduced ROS and lipid peroxidation and thereby improved the growth, photosynthesis and leaf ultrastructure, indicating AR stress tolerance in tomato plants. An earlier study showed that less damage to chloroplast and comparatively thicker leaf tissues were observed in melatonin-treated plants with respect to the stressed plants [111]. In addition, the mitigation of chlorophyll degradation and improvement in photosynthesis of plants was observed by the application of exogenous melatonin under abiotic stress [113,114]. Numerous previous studies also revealed that exogenous melatonin has complex and influential effects on scavenging ROS, activating antioxidant enzymes and non-enzymes under various harsh conditions [50,115-118]. Debnath et al. [57] found $100 \mu \mathrm{M}$ melatonin treatment as the most effective dose among different used doses in AR-stressed tomato plants.

In addition, other experimental results [119] exhibited that SAR-treated tomato plants had improved activities of enzymatic antioxidants in tomato as well as high amounts of health-promoting bioactive compounds in fruits, whereas tomato production greatly decreased. The stress-induced enzymatic antioxidants in tomato might play a significant role to accelerate protection mechanisms by attenuating oxidative stress under different environmental stress conditions, which results in improved biochemical properties of tomato, but is unable to hinder the detrimental effects of stress to yields [120-124]. In contrast, the supplementation of melatonin in AR-stressed plants showed more augmentation of the enzymatic antioxidants and different bioactive compounds in fruits, as well as a sharp increase of the yield attributes of tomatoes [119]. Consistently, it was documented that melatonin enhanced fruit quality during the developmental and ripening stages by reducing degradation of the cell wall and intercellular adhesion [125]. Moreover, these results complied with the concept of other researchers who state that the application of melatonin boosted the stress tolerance of plants by uplifting ROS-detoxifying antioxidants against oxidative injury, improving crop yield under abiotic stress conditions $[47,126]$. In a recent study, Debnath et al. [119] revealed that melatonin supplementation could mitigate the negative impact of AR stress on tomato fruits by strengthening the antioxidant system and also by increasing health-promoting antioxidant compounds in fruits, and eventually, increase the yield. 
It was reported that DEGs were influenced by AR stress in tomato plants, and foliar spray of melatonin in AR-stressed plants showed remarkable expression of DEGs to improve AR stress tolerance in tomato plants [18]. Their results [18] of RNA-sequence and qRT-PCR suggested that the regulatory genes of different secondary metabolites were downregulated by AR treatment in relation to control vs AR-stressed tomato plant (Table 1). Similar to these results, Liu et al. [127] observed that AR treatment changed the expression pattern of differential genes and also the genes associated with secondary metabolites in plants. To the contrary, the use of melatonin in AR-stressed plants caused upregulation of secondary gene expression in control vs melatonin-treated AR-stressed plants, and ARstressed plants vs melatonin-treated AR-stressed plants (Table 1) [18]. In support of these outcomes, many other experimental outputs also reported that exogenous melatonin upregulates the expression of genes linked with different metabolites and thus, enhances stress tolerance in plants [128-130]. In addition, transcriptome analysis also reported that more than $30 \mathrm{TF}$ family genes are involved in stress signal transduction and biosynthesis of plant secondary metabolites under abiotic stress [88-90]. According to qRT-PCR and RNAsequence results of the study of Debnath et al. [18], it was stated that the expression of MYB, WRKY, ERF and bZIP were down regulated by AR treatment in relation to control (Table 1). Liu et al. [15] also observed the down regulation of TF-related genes in Arabidopsis under AR stress conditions. Conversely, the results of Reference [18] also revealed that the foliar spray of melatonin in AR-stressed plants enhanced the upregulation of stressresponsive TF-related genes to lighten SAR stress. It has been perceived that application of melatonin adjusts the expression of TFs such as bZIP, MYB, WRKY and ERF, which accelerates the expression of ROS-scavenging enzyme-encoding genes to promote abiotic stress tolerance [131-133]. However, Debnath et al. [18] exposed the genes associated with the activation of antioxidants, modulation of secondary metabolites and their pattern of expression to melatonin treatment under AR stress.

Table 1. Expression of differentially expressed genes (DEGs) through RNA sequence (log2 fold change) and qRT-PCR fold changes in tomato plant under AR stress conditions and melatonin supplementation [18].

\begin{tabular}{|c|c|c|c|}
\hline \multirow{2}{*}{ Gene Description } & \multirow{2}{*}{ Function } & \multicolumn{2}{|c|}{ Expression } \\
\hline & & $\begin{array}{l}\text { Control vs. } \\
\text { AR-Stressed Plants }\end{array}$ & $\begin{array}{c}\text { AR-Stressed Plants vs. } \\
\text { AR-Stressed Plants Treated } \\
\text { with Melatonin }\end{array}$ \\
\hline $\begin{array}{c}\text { Caffeoyl-CoA } \\
\text { O-methyltransferase-like }\end{array}$ & $\begin{array}{l}\text { Biosynthesis of secondary } \\
\text { metabolites, } \\
\text { Phenylpropanoid } \\
\text { biosynthesis, } \\
\text { Flavonoid biosynthesis, } \\
\text { Stilbenoid, diarylheptanoid } \\
\text { and gingerol biosynthesis, } \\
\text { Phenylalanine metabolism, } \\
\text { Metabolic pathways }\end{array}$ & Downregulated & Upregulated \\
\hline $\begin{array}{l}\text { Probable galacturonosyl } \\
\text { transferase-like 10-like }\end{array}$ & $\begin{array}{c}\text { Biosynthesis of secondary } \\
\text { metabolites, } \\
\text { Starch and sucrose } \\
\text { metabolism, } \\
\text { Amino sugar and nucleotide } \\
\text { sugar metabolism }\end{array}$ & Downregulated & Upregulated \\
\hline
\end{tabular}


Table 1. Cont.

\begin{tabular}{|c|c|c|c|}
\hline \multirow{2}{*}{ Gene Description } & \multirow{2}{*}{ Function } & \multicolumn{2}{|c|}{ Expression } \\
\hline & & $\begin{array}{l}\text { Control vs. } \\
\text { AR-Stressed Plants }\end{array}$ & $\begin{array}{l}\text { AR-Stressed Plants vs. } \\
\text { AR-Stressed Plants Treated } \\
\text { with Melatonin }\end{array}$ \\
\hline Cytochrome P450 94A1-like & $\begin{array}{c}\text { Biosynthesis of secondary } \\
\text { metabolites, } \\
\text { Cutin, suberine and wax } \\
\text { biosynthesis, } \\
\text { Stilbenoid, diarylheptanoid } \\
\text { and gingerol biosynthesis, } \\
\text { Metabolic pathways, } \\
\text { Limonene and } \\
\text { pinene degradation }\end{array}$ & Downregulated & Upregulated \\
\hline $\begin{array}{c}\text { Salutaridinol } \\
\text { 7-O-acetyltransferase-like }\end{array}$ & $\begin{array}{l}\text { Biosynthesis of secondary } \\
\text { metabolites, } \\
\text { Phenylpropanoid } \\
\text { biosynthesis, } \\
\text { Flavonoid biosynthesis, } \\
\text { Stilbenoid, diarylheptanoid } \\
\text { and gingerol biosynthesis }\end{array}$ & Downregulated & Upregulated \\
\hline 4-coumarate-CoA ligase 2-like & $\begin{array}{c}\text { Biosynthesis of secondary } \\
\text { metabolites, } \\
\text { Phenylpropanoid } \\
\text { biosynthesis, } \\
\text { Phenylalanine metabolism, } \\
\text { Metabolic pathways, } \\
\text { Ubiquinone and other } \\
\text { terpenoid-quinone } \\
\text { biosynthesis }\end{array}$ & Downregulated & Upregulated \\
\hline $\begin{array}{c}\text { Anthocyanidin } \\
\text { 3-O-glucosyltransferase-like }\end{array}$ & $\begin{array}{c}\text { Biosynthesis of secondary } \\
\text { metabolites, } \\
\text { Metabolic pathways, } \\
\text { Flavone and flavonol } \\
\text { biosynthesis, } \\
\text { Anthocyanin biosynthesis }\end{array}$ & Downregulated & Downregulated \\
\hline $\begin{array}{l}\text { Secologanin synthase-like } \\
\text { isoform } 1\end{array}$ & $\begin{array}{l}\text { Biosynthesis of secondary } \\
\text { metabolites, } \\
\text { Metabolic pathways, } \\
\text { Brassinosteroid biosynthesis, } \\
\text { Zeatin biosynthesis }\end{array}$ & Downregulated & Upregulated \\
\hline $\begin{array}{l}\text { Caffeoyl-CoA O-methyl } \\
\text { transferase-like isoform } 2\end{array}$ & $\begin{array}{c}\text { Biosynthesis of secondary } \\
\text { metabolites, } \\
\text { Phenylpropanoid } \\
\text { biosynthesis, } \\
\text { Flavonoid biosynthesis, } \\
\text { Stilbenoid, diarylheptanoid } \\
\text { and gingerol biosynthesis, } \\
\text { Phenylalanine metabolism, } \\
\text { Metabolic pathways }\end{array}$ & Downregulated & Downregulated \\
\hline $\begin{array}{l}\text { S-adenosylmethionine } \\
\text { decarboxylase proenzyme-like }\end{array}$ & $\begin{array}{c}\text { Arginine and proline } \\
\text { metabolism, } \\
\text { Cysteine and methionine } \\
\text { metabolism, } \\
\text { Metabolic pathways }\end{array}$ & Downregulated & Upregulated \\
\hline
\end{tabular}


Table 1. Cont.

\begin{tabular}{cccc}
\hline Gene Description & Function & Expression & $\begin{array}{c}\text { AR-Stressed Plants vs. } \\
\text { AR-Stressed Plants Treated } \\
\text { with Melatonin }\end{array}$ \\
\cline { 2 - 4 } $\begin{array}{c}\text { Cyanidin-3-O-glucoside 2-O- } \\
\text { glucuronosyltransferase-like }\end{array}$ & $\begin{array}{c}\text { Flavone and flavonol } \\
\text { biosynthesis, } \\
\text { Zeatin biosynthesis }\end{array}$ & $\begin{array}{c}\text { Control vs. } \\
\text { AR-Stressed Plants }\end{array}$ & Upregulated \\
\hline $\begin{array}{c}\text { Abscisic acid 8'-hydroxylase } \\
\text { 1-like }\end{array}$ & Carotenoid biosynthesis & Downregulated & Upregulated \\
\hline MYB-related protein & $\begin{array}{c}\text { Stress-responsive MYB family } \\
\text { transcriptional factor }\end{array}$ & Downregulated & Upregulated \\
\hline $\begin{array}{c}\text { Probable WRKY transcription } \\
\text { factor 33-like }\end{array}$ & $\begin{array}{c}\text { Stress-responsive WRKY } \\
\text { family transcriptional factor } \\
\text { Plant-pathogen interaction }\end{array}$ & Downregulated & Upregulated \\
\hline $\begin{array}{c}\text { Ethylene-responsive } \\
\text { transcription factor 1-like }\end{array}$ & $\begin{array}{c}\text { Stress-responsive ERF family } \\
\text { transcriptional factors } \\
\text { Plant hormone signal } \\
\text { transduction }\end{array}$ & Downregulated & Upregulated \\
\hline $\begin{array}{l}\text { Uncharacterized protein } \\
\text { LOC101262884 isoform 1 }\end{array}$ & $\begin{array}{c}\text { Stress-responsive bZIP family } \\
\text { transcriptional factor }\end{array}$ & Downregulated & Upregulated \\
\hline
\end{tabular}

Therefore, the series of experimental results $[18,57,119]$ reported that the use of melatonin might be a potential technique for enriching plant tolerance by modulating growth, physiological and molecular activities in AR condition. Figure 3 presents a summary showing how exogenous melatonin influences cellular mechanism of AR stress tolerance in plants. Melatonin can freely penetrate the cell membranes because of its amphiphilic nature. Melatonin directly quenches ROS and also upsurges the extent of antioxidant activity to accelerate ROS scavenging capacity, thereby defending cellular damage and improving AR stress tolerance.

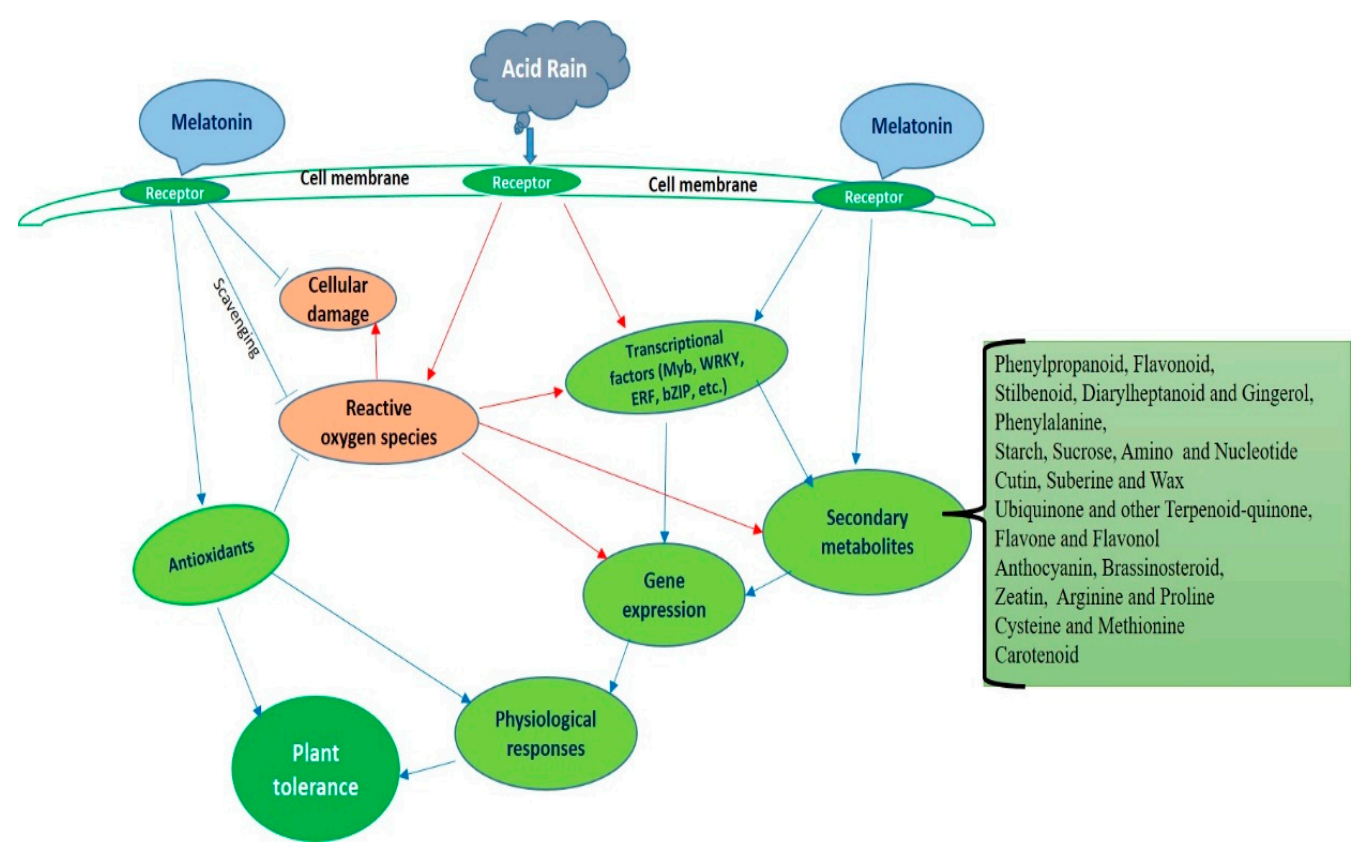

Figure 3. Melatonin-mediated acid rain stress tolerance and detoxification mechanism in plants. Modified from Debnath et al. [18]. 


\section{Conclusions and Future Prospective}

The current review was carried out to understand the responses of plants to AR stress and elucidate the possible impact of silicon, glutathione and melatonin in mediating AR stress tolerance. The major findings indicated that AR stress reduces the normal plant growth and photosynthesis by stimulating ROS generation and inhibiting subsequent pathways. While the ROS detoxification system was found to be effectively activated and improved normal plant growth and productivity by the application of bio-stimulators under such circumstances. Hence, the stimulation of natural biosynthesis and/or exogenous supplementation of the above-mentioned bio-regulators might establish a new state of equilibrium to contribute to the inherent plasticity of plants in order to combat and detoxify the stress generated by AR. Numerous articles have explored that foliar application of silicon, glutathione and melatonin effectively considerably ameliorates the toxicity of AR in many plant species by mitigating the growth, photosynthetic inhibitors, leaf ultrastructural changes and antioxidant activities in plants during AR stress (Figure 4). Besides, melatonin applications during AR stress enhanced not only the quality traits but also the bioactive antioxidant compounds in fruits, which has enormous health benefits. Furthermore, the current review also summarized that in addition to physiological responses, the protective roles of exogenous silicon, glutathione and melatonin to combat the AR stress are highly involved in the regulation of transcription factors like bZIP, MYB, WRKY and ERF in plants.

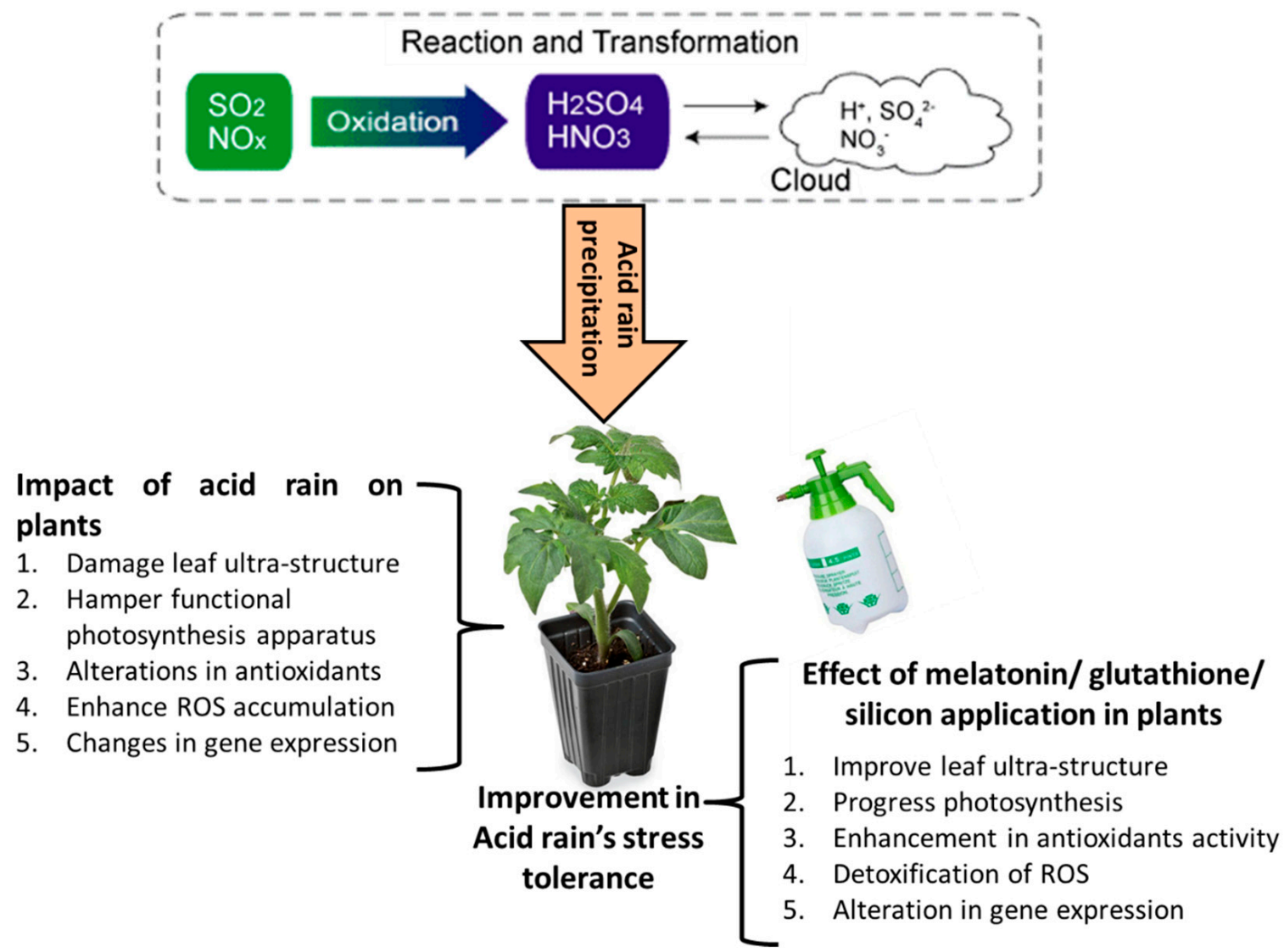

Figure 4. The role of melatonin, glutathione and silicon in mitigating the acid rain effects in plants.

Therefore, recent advances of the physiological and molecular activities of silicon, glutathione and melatonin in plants have confirmed their prime roles to improve AR stress tolerance. However, the genetic evidence and the subsequent signaling cascades in the action of AR stress tolerance have not yet been deeply studied, and thus require further investigations. Hopefully, additional underlying mechanisms and core pathways to explain 
the high efficiency of the argued bioactive compounds in enhancing the tolerance of plants to AR stress will be uncovered in the near future. Hence, the adoption of new tactics in mitigating the consequences of AR stress on crops' growth and productivity have promise in escalating agricultural extension, where AR is a restrictive factor.

Author Contributions: B.D. conceived, designed and wrote the manuscript. A.S., M.S.I., M.K.H. and M.L. helped in writing and revising the manuscript. D.Q. conceived, reviewed and finalized the manuscript. All authors have read and agreed to the published version of the manuscript.

Funding: This study was partially funded by National Natural Science Grant of China (Award no. 30400061), Natural Science Foundation of Fujian Province, China (2011J01082) and Special Fund for Science and Technology Innovation of FAFU (CXZX2016107).

Acknowledgments: We are grateful to the researchers who have contributed to this field.

Conflicts of Interest: The authors declare no conflict of interest.

\section{References}

1. Dwivedi, A.; Tripathi, B. Pollution tolerance and distribution pattern of plants in surrounding area of coal-fired industries. J. Environ. Biol. 2007, 28, 257-263.

2. Bouwman, A.F.; Vuuren, D.P.V.; Derwent, R.G.; Posch, M. A global analysis of acidification and eutrophication of terrestrial ecosystems. Water Air Soil Pollut. 2002, 141, 349-382. [CrossRef]

3. Feng, Z. Impacts and control strategies of acid deposition on terrestrial ecosystems in china. Eng. Sci. 2000, 9, 5-11.

4. Chen, J.; Li, W.; Gao, F. Biogeochemical effects of forest vegetation on acid precipitation-related water chemistry: A case study in southwest china. J. Environ. Monit. 2010, 12, 1799-1806. [CrossRef]

5. Feng, Z. Ecological effects and control strategies of acid deposition on ecosystems in china. Yunnan Environ. Sci. 2000, 19, 1-6.

6. Fairfax, J.; Lepp, N. Effect of simulated 'acid rain'on cation loss from leaves. Nature 1975, 255, 324. [CrossRef]

7. Seinfeld, J.H.; Pandis, S.N. Atmospheric Chemistry and Physics: From Air Pollution to Climate Change; John Wiley \& Sons: Hoboken, NJ, USA, 2012.

8. Ren, X.; Zhu, J.; Liu, H.; Xu, X.; Liang, C. Response of antioxidative system in rice (Oryza sativa) leaves to simulated acid rain stress. Ecotoxicol. Environ. Saf. 2018, 148, 851-856. [CrossRef]

9. Liu, J.; Zhou, G.; Yang, C.; Ou, Z.; Peng, C. Responses of chlorophyll fluorescence and xanthophyll cycle in leaves of Schima superba Gardn. \& Champ. and Pinus massoniana Lamb. to simulated acid rain at dinghushan biosphere reserve, china. Acta Physiol. Plant. 2007, 29, 33-38.

10. Liu, T.-W.; Wu, F.-H.; Wang, W.-H.; Chen, J.; Li, Z.-J.; Dong, X.-J.; Patton, J.; Pei, Z.-M.; Zheng, H.-L. Effects of calcium on seed germination, seedling growth and photosynthesis of six forest tree species under simulated acid rain. Tree Physiol. 2011, 31, 402-413. [CrossRef]

11. Dolatabadian, A.; Sanavy, S.A.M.M.; Gholamhoseini, M.; Joghan, A.K.; Majdi, M.; Kashkooli, A.B. The role of calcium in improving photosynthesis and related physiological and biochemical attributes of spring wheat subjected to simulated acid rain. Physiol. Mol. Biol. Plants 2013, 19, 189-198. [CrossRef]

12. Chen, J.; Wang, W.-H.; Liu, T.-W.; Wu, F.-H.; Zheng, H.-L. Photosynthetic and antioxidant responses of Liquidambar formosana and Schima superba seedlings to sulfuric-rich and nitric-rich simulated acid rain. Plant Physiol. Biochem. 2013, 64, 41-51. [CrossRef]

13. Kováčik, J.; Klejdus, B.; Bačkor, M.; Stork, F.; Hedbavny, J. Physiological responses of root-less epiphytic plants to acid rain. Ecotoxicology 2011, 20, 348-357. [CrossRef]

14. Wen, K.; Liang, C.; Wang, L.; Hu, G.; Zhou, Q. Combined effects of lanthanumion and acid rain on growth, photosynthesis and chloroplast ultrastructure in soybean seedlings. Chemosphere 2011, 84, 601-608. [CrossRef]

15. Liu, T.W.; Niu, L.; Fu, B.; Chen, J.; Wu, F.H.; Chen, J.; Wang, W.H.; Hu, W.J.; He, J.X.; Zheng, H.L. A transcriptomic study reveals differentially expressed genes and pathways respond to simulated acid rain in Arabidopsis thaliana. Genome 2013, 56, 49-60. [CrossRef]

16. Ju, S.; Wang, L.; Chen, J. Effects of silicon on the growth, photosynthesis and chloroplast ultrastructure of Oryza sativa L. seedlings under acid rain stress. Silicon 2020, 12, 655-664. [CrossRef]

17. Xalxo, R.; Keshavkant, S. Melatonin, glutathione and thiourea attenuates lead and acid rain-induced deleterious responses by regulating gene expression of antioxidants in Trigonella foenum graecum L. Chemosphere 2019, 221, 1-10. [CrossRef] [PubMed]

18. Debnath, B.; Li, M.; Liu, S.; Pan, T.; Ma, C.; Qiu, D. Melatonin-mediate acid rain stress tolerance mechanism through alteration of transcriptional factors and secondary metabolites gene expression in tomato. Ecotoxicol. Environ. Saf. 2020, 200, 110720. [CrossRef] [PubMed]

19. Debona, D.; Rodrigues, F.A.; Datnoff, L.E. Silicon's role in abiotic and biotic plant stresses. Annu. Rev. Phytop. 2017, 55, 85-107. [CrossRef]

20. Kleiber, T.; Calomme, M.; Borowiak, K. The effect of choline-stabilized orthosilicic acid on microelements and silicon concentration, photosynthesis activity and yield of tomato grown under Mn stress. Plant Physiol. Biochem. 2015, 96, 180-188. [CrossRef] [PubMed] 
21. Adrees, M.; Ali, S.; Rizwan, M.; Zia-ur-Rehman, M.; Ibrahim, M.; Abbas, F.; Farid, M.; Qayyum, M.F.; Irshad, M.K. Mechanisms of silicon-mediated alleviation of heavy metal toxicity in plants: A review. Ecotoxicol. Environ. Saf. 2015, 119, 186-197. [CrossRef] [PubMed]

22. Fortunato, A.A.; Rodrigues, F.Á.; do Nascimento, K.J.T. Physiological and biochemical aspects of the resistance of banana plants to fusarium wilt potentiated by silicon. Phytopathology 2012, 102, 957-966. [CrossRef]

23. Resende, R.; Rodrigues, F.; Gomes, R.; Nascimento, K. Microscopic and biochemical aspects of sorghum resistance to anthracnose mediated by silicon. Ann. Appl. Biol. 2013, 163, 114-123. [CrossRef]

24. Hasanuzzaman, M.; Nahar, K.; Rahman, A.; Mahmud, J.A.; Alharby, H.F.; Fujita, M. Exogenous glutathione attenuates leadinduced oxidative stress in wheat by improving antioxidant defense and physiological mechanisms. J. Plant. Inter. 2018, 13, 203-212. [CrossRef]

25. Noctor, G.; Mhamdi, A.; Chaouch, S.; Han, Y.; Neukermans, J.; Marquez-Garcia, B.; Queval, G.; Foyer, C.H. Glutathione in plants: An integrated overview. Plant. Cell Environ. 2012, 35, 454-484. [CrossRef]

26. Rodrigo, M.A.M.; Anjum, N.A.; Heger, Z.; Zitka, O.; Vojtech, A.; Pereira, E.; Kizek, R. Role of phytochelatins in redox caused stress in plants and animals. In Abiotic and Biotic Stress in Plants-Recent Advances and Future Perspectives; IntechOpen: London, UK, 2016.

27. Hasanuzzaman, M.; Nahar, K.; Hossain, M.; Mahmud, J.A.; Rahman, A.; Inafuku, M.; Oku, H.; Fujita, M. Coordinated actions of glyoxalase and antioxidant defense systems in conferring abiotic stress tolerance in plants. Int. J. Mol. Sci. 2017, 18, 200. [CrossRef] [PubMed]

28. Hardeland, R.; Cardinali, D.P.; Srinivasan, V.; Spence, D.W.; Brown, G.M.; Pandi-Perumal, S.R. Melatonin-A pleiotropic, orchestrating regulator molecule. Prog. Neurobiol. 2011, 93, 350-384. [CrossRef]

29. Yu, K.; Deng, S.-L.; Sun, T.-C.; Li, Y.-Y.; Liu, Y.-X. Melatonin regulates the synthesis of steroid hormones on male reproduction: A review. Molecules 2018, 23, 447. [CrossRef]

30. Tan, D.X.; Xu, B.; Zhou, X.; Reiter, R.J. Pineal calcification, melatonin production, aging, associated health consequences and rejuvenation of the pineal gland. Molecules 2018, 23, 301. [CrossRef]

31. Manchester, L.C.; Coto-Montes, A.; Boga, J.A.; Andersen, L.P.H.; Zhou, Z.; Galano, A.; Vriend, J.; Tan, D.X.; Reiter, R.J. Melatonin An ancient molecule that makes oxygen metabolically tolerable. J. Pineal Res. 2015, 59, 403-419. [CrossRef]

32. Beilby, M.J.; Turi, C.E.; Baker, T.C.; Tymm, F.J.; Murch, S.J. Circadian changes in endogenous concentrations of indole-3-acetic acid, melatonin, serotonin, abscisic acid and jasmonic acid in characeae (Chara australis Brown). Plant. Signal. Behav. 2015, 10, e1082697. [CrossRef]

33. Shiu, S.Y.; Pang, B.; Tam, C.W.; Yao, K.M. Signal transduction of receptor-mediated antiproliferative action of melatonin on human prostate epithelial cells involves dual activation of $\mathrm{g} \alpha \mathrm{s}$ and $\mathrm{g} \alpha \mathrm{q}$ proteins. J. Pineal Res. 2010, 49, 301-311. [CrossRef]

34. Imbesi, M.; Arslan, A.D.; Yildiz, S.; Sharma, R.; Gavin, D.; Tun, N.; Manev, H.; Uz, T. The melatonin receptor mt1 is required for the differential regulatory actions of melatonin on neuronal 'clock'gene expression in striatal neurons in vitro. J. Pineal Res. 2009, 46, 87-94. [CrossRef]

35. Tan, D.X.; Reiter, R.J.; Manchester, L.C.; Yan, M.; El-Sawi, M.; Sainz, R.M.; Mayo, J.C.; Kohen, R.; Allegra, M.; Hardeland, R. Chemical and physical properties and potential mechanisms: Melatonin as a broad spectrum antioxidant and free radical scavenger. Curr. Top. Med. Chem. 2002, 2, 181-197. [CrossRef]

36. Schaefer, M.; Hardeland, R. The melatonin metabolite n1-acetyl-5-methoxykynuramine is a potent singlet oxygen scavenger. J. Pineal Res. 2009, 46, 49-52. [CrossRef]

37. Acuña-Castroviejo, D.; Martín, M.; Macías, M.; Escames, G.; León, J.; Khaldy, H.; Reiter, R.J. Melatonin, mitochondria, and cellular bioenergetics. J. Pineal Res. 2001, 30, 65-74. [CrossRef] [PubMed]

38. Nopparat, C.; Porter, J.E.; Ebadi, M.; Govitrapong, P. The mechanism for the neuroprotective effect of melatonin against methamphetamine-induced autophagy. J. Pineal Res. 2010, 49, 382-389. [CrossRef]

39. Um, H.J.; Kwon, T.K. Protective effect of melatonin on oxaliplatin induced apoptosis through sustained mcl-1 expression and antioxidant action in renal Carcinoma caki cells. J. Pineal Res. 2010, 49, 283-290. [CrossRef]

40. Xu, S.C.; He, M.D.; Zhong, M.; Zhang, Y.W.; Wang, Y.; Yang, L.; Yang, J.; Yu, Z.P.; Zhou, Z. Melatonin protects against nickel induced neurotoxicity in vitro by reducing oxidative stress and maintaining mitochondrial function. J. Pineal Res. 2010, 49, 86-94. [CrossRef]

41. Tan, D.X.; Hardeland, R.; Manchester, L.C.; Paredes, S.D.; Korkmaz, A.; Sainz, R.M.; Mayo, J.C.; Fuentes-Broto, L.; Reiter, R.J. The changing biological roles of melatonin during evolution: From an antioxidant to signals of darkness, sexual selection and fitness. Biol. Rev. 2010, 85, 607-623. [CrossRef] [PubMed]

42. Xu, W.-Z.; Deng, X.-P.; Xu, B.-C.; Gao, Z.-J.; Ding, W.-L. Photosynthetic activity and efficiency of Bothriochloa ischaemum and Lespedeza davurica in mixtures across growth periods under water stress. Acta Physiol. Plant. 2014, 36, 1033-1044. [CrossRef]

43. Liu, J.; Zhao, Y.; Song, H.; Chen, J.; Long, Y. Antagonism or synergism? Combined effects of enhanced uv-b radiation and acid rain on photosynthesis in seedlings of two c4 plants. Acta Ecol. Sin. 2020, 40, 72-80. [CrossRef]

44. Zhang, C.; Yi, X.; Gao, X.; Wang, M.; Shao, C.; Lv, Z.; Chen, J.; Liu, Z.; Shen, C. Physiological and biochemical responses of tea seedlings (Camellia sinensis) to simulated acid rain conditions. Ecotoxicol. Environ. Saf. 2020, 192, 110315. [CrossRef]

45. Reza Yousefi, A.; Rashidi, S.; Moradi, P.; Mastinu, A. Germination and seedling growth responses of zygophyllum fabago, salsola kali 1. And atriplex canescens to peg-induced drought stress. Environments 2020, 7, 107. [CrossRef] 
46. Zuo, Z.; Wang, B.; Ying, B.; Zhou, L.; Zhang, R. Monoterpene emissions contribute to thermotolerance in Cinnamomum camphora. Trees 2017, 31, 1759-1771. [CrossRef]

47. Tan, D.-X.; Hardeland, R.; Manchester, L.C.; Korkmaz, A.; Ma, S.; Rosales-Corral, S.; Reiter, R.J. Functional roles of melatonin in plants, and perspectives in nutritional and agricultural science. J. Exp. Bot. 2011, 63, 577-597. [CrossRef]

48. Gao, P.; Zuo, Z.; Wu, X.; Gao, Y.; Gao, R.; Zhang, R. Effects of cycloheximide on photosynthetic abilities, reflectance spectra and fluorescence emission spectra in Phyllostachys edulis. Trees 2016, 30, 719-732. [CrossRef]

49. Xu, W.; Cai, S.Y.; Zhang, Y.; Wang, Y.; Ahammed, G.J.; Xia, X.J.; Shi, K.; Zhou, Y.H.; Yu, J.Q.; Reiter, R.J. Melatonin enhances thermotolerance by promoting cellular protein protection in tomato plants. J. Pineal Res. 2016, 61, 457-469. [CrossRef]

50. Ding, F.; Liu, B.; Zhang, S. Exogenous melatonin ameliorates cold-induced damage in tomato plants. Sci. Hortic. 2017, 219, 264-271. [CrossRef]

51. Zhou, X.; Zhao, H.; Cao, K.; Hu, L.; Du, T.; Baluška, F.; Zou, Z. Beneficial roles of melatonin on redox regulation of photosynthetic electron transport and synthesis of $\mathrm{d} 1$ protein in tomato seedlings under salt stress. Front. Plant. Sci. 2016, 7, 1823. [CrossRef]

52. Liu, N.; Jin, Z.; Wang, S.; Gong, B.; Wen, D.; Wang, X.; Wei, M.; Shi, Q. Sodic alkaline stress mitigation with exogenous melatonin involves reactive oxygen metabolism and ion homeostasis in tomato. Sci. Hortic. 2015, 181, 18-25. [CrossRef]

53. Liu, J.; Wang, W.; Wang, L.; Sun, Y. Exogenous melatonin improves seedling health index and drought tolerance in tomato. Plant. Growth Regul. 2015, 77, 317-326. [CrossRef]

54. Hasan, M.K.; Ahammed, G.J.; Yin, L.; Shi, K.; Xia, X.; Zhou, Y.; Yu, J.; Zhou, J. Melatonin mitigates cadmium phytotoxicity through modulation of phytochelatins biosynthesis, vacuolar sequestration, and antioxidant potential in Solanum lycopersicum $\mathrm{L}$. Front. Plant. Sci. 2015, 6, 601. [CrossRef]

55. Hu, H.; Wang, L.; Liao, C.; Fan, C.; Zhou, Q.; Huang, X. Combined effects of lead and acid rain on photosynthesis in soybean seedlings. Biol. Trace Elem. Res. 2014, 161, 136-142. [CrossRef]

56. Debnath, B.; Ahammed, G.J. Effect of acid rain on plant growth and development: Physiological and molecular interventions. In Contaminants in Agriculture; Springer: Berlin/Heidelberg, Germany, 2020; pp. 103-114.

57. Debnath, B.; Hussain, M.; Irshad, M.; Mitra, S.; Li, M.; Liu, S.; Qiu, D. Exogenous melatonin mitigates acid rain stress to tomato plants through modulation of leaf ultrastructure, photosynthesis and antioxidant potential. Molecules 2018, 23, 388. [CrossRef]

58. Debnath, B.; Irshad, M.; Mitra, S.; Li, M.; Liu, S.; Rizwan, H.M.; Pan, T.; Qiu, D. Acid rain deposition modulates photosynthesis, enzymatic and non-enzymatic antioxidant activities in tomato. Int. J. Environ. Res. 2018, 12, 203-214. [CrossRef]

59. Zhang, J.; Li, H.; Xu, B.; Li, J.; Huang, B. Exogenous melatonin suppresses dark-induced leaf senescence by activating the superoxide dismutase-catalase antioxidant pathway and down-regulating chlorophyll degradation in excised leaves of perennial ryegrass (Lolium perenne L.). Front. Plant. Sci. 2016, 7, 1500. [CrossRef]

60. Wang, M.; Zhang, T.; Ding, F. Exogenous melatonin delays methyl jasmonate-triggered senescence in tomato leaves. Agronomy 2019, 9, 795. [CrossRef]

61. Liu, M.; Korpelainen, H.; Dong, L.; Yi, L. Physiological responses of Elaeocarpus glabripetalus seedlings exposed to simulated acid rain and cadmium. Ecotoxicol. Environ. Saf. 2019, 175, 118-127. [CrossRef]

62. Kummerová, M.; Krulová, J.; Zezulka, Š.; Tříska, J. Evaluation of fluoranthene phytotoxicity in pea plants by hill reaction and chlorophyll fluorescence. Chemosphere 2006, 65, 489-496. [CrossRef]

63. Zhang, F.; Cheng, M.; Sun, Z.; Wang, L.; Zhou, Q.; Huang, X. Combined acid rain and lanthanum pollution and its potential ecological risk for nitrogen assimilation in soybean seedling roots. Environ. Pollut. 2017, 231, 524-532. [CrossRef]

64. Apel, K.; Hirt, H. Reactive oxygen species: Metabolism, oxidative stress, and signal transduction. Annu. Rev. Plant. Biol. 2004, 55, 373-399. [CrossRef] [PubMed]

65. Schutzendubel, A.; Polle, A. Plant responses to abiotic stresses: Heavy metal-induced oxidative stress and protection by mycorrhization. J. Exp. Bot. 2002, 53, 1351-1365. [CrossRef]

66. Di Toppi, L.S.; Gabbrielli, R. Response to cadmium in higher plants. Environ. Exp. Bot. 1999, 41, 105-130. [CrossRef]

67. Quan, L.J.; Zhang, B.; Shi, W.W.; Li, H.Y. Hydrogen peroxide in plants: A versatile molecule of the reactive oxygen species network. J. Integr. Plant. Biol. 2008, 50, 2-18. [CrossRef]

68. Garg, N.; Manchanda, G. Ros generation in plants: Boon or bane? Plant. Biosyst. 2009, 143, 81-96. [CrossRef]

69. Esterbauer, H.; Schaur, R.J.; Zollner, H. Chemistry and biochemistry of 4-hydroxynonenal, malonaldehyde and related aldehydes. Free Radic. Bio. Med. 1991, 11, 81-128. [CrossRef]

70. Ayala, A.; Muñoz, M.F.; Argüelles, S. Lipid peroxidation: Production, metabolism, and signaling mechanisms of malondialdehyde and 4-hydroxy-2-nonenal. Oxid. Med. Cell. Longev. 2014, 2014. [CrossRef] [PubMed]

71. Heath, R.L.; Packer, L. Photoperoxidation in isolated chloroplasts: I. Kinetics and stoichiometry of fatty acid peroxidation. Arch. Biochem. Biophys. 1968, 125, 189-198. [CrossRef]

72. Montillet, J.-L.; Chamnongpol, S.; Rustérucci, C.; Dat, J.; Van De Cotte, B.; Agnel, J.-P.; Battesti, C.; Inzé, D.; Van Breusegem, F.; Triantaphylidès, C. Fatty acid hydroperoxides and $\mathrm{H}_{2} \mathrm{O}_{2}$ in the execution of hypersensitive cell death in tobacco leaves. Plant. Physiol. 2005, 138, 1516-1526. [CrossRef]

73. Qiao, F.; Zhang, X.-M.; Liu, X.; Chen, J.; Hu, W.-J.; Liu, T.-W.; Liu, J.-Y.; Zhu, C.-Q.; Ghoto, K.; Zhu, X.-Y. Elevated nitrogen metabolism and nitric oxide production are involved in arabidopsis resistance to acid rain. Plant. Physiol. Biochem. 2018, 127, 238-247. [CrossRef] 
74. Xia, B.; Sun, Z.; Wang, L.; Zhou, Q.; Huang, X. Analysis of the combined effects of lanthanum and acid rain, and their mechanisms, on nitrate reductase transcription in plants. Ecotoxicol. Environ. Saf. 2017, 138, 170-178. [CrossRef]

75. Ju, S.; Wang, L.; Yin, N.; Li, D.; Wang, Y.; Zhang, C. Silicon alleviates simulated acid rain stress of Oryza sativa L. seedlings by adjusting physiology activity and mineral nutrients. Protoplasma 2017, 254, 2071-2081. [CrossRef] [PubMed]

76. Huang, J.; Wang, H.; Zhong, Y.; Huang, J.; Fu, X.; Wang, L.; Teng, W. Growth and physiological response of an endangered tree, Horsfieldia hainanensis Merr. to simulated sulfuric and nitric acid rain in southern china. Plant. Physiol. Biochem. 2019, 144, 118-126. [CrossRef] [PubMed]

77. Fontenele, N.M.B.; Otoch, M.d.L.O.; Gomes-Rochette, N.F.; de Menezes Sobreira, A.C.; Barreto, A.A.G.C.; de Oliveira, F.D.B.; Costa, J.H.; Borges, S.d.S.S.; do Nascimento, R.F.; de Melo, D.F. Effect of lead on physiological and antioxidant responses in two Vigna unguiculata cultivars differing in pb-accumulation. Chemosphere 2017, 176, 397-404. [CrossRef]

78. Gill, S.S.; Tuteja, N. Reactive oxygen species and antioxidant machinery in abiotic stress tolerance in crop plants. Plant. Physiol. Biochem. 2010, 48, 909-930. [CrossRef]

79. Asada, K. The water-water cycle in chloroplasts: Scavenging of active oxygens and dissipation of excess photons. Annu. Rev. Plant. Biol. 1999, 50, 601-639. [CrossRef]

80. Chen, F.; Wang, F.; Wu, F.; Mao, W.; Zhang, G.; Zhou, M. Modulation of exogenous glutathione in antioxidant defense system against cd stress in the two barley genotypes differing in cd tolerance. Plant. Physiol. Biochem. 2010, 48, 663-672. [CrossRef]

81. Szabados, L.; Savoure, A. Proline: A multifunctional amino acid. Trends Plant. Sci. 2010, 15, 89-97. [CrossRef] [PubMed]

82. Yan, Y.; Jing, X.; Tang, H.; Li, X.; Gong, B.; Shi, Q. Using transcriptome to discover a novel melatonin-induced sodic alkaline stress resistant pathway in Solanum lycopersicum L. Plant. Cell Physiol. 2019, 60, 2051-2064. [CrossRef]

83. Zheng, S.; Pan, T.; Ma, C.; Qiu, D. Differential gene expression of longan under simulated acid rain stress. B. Environ. Contam. Tox. 2017, 98, 726-731. [CrossRef]

84. Liu, T.; Ma, J.; Li, M.; Pan, T.; Ma, C.; Qiu, D. Cdna-aflp analysis reveals inducible gene expression in tomato leaves in response to simulated acid rain. Appl. Ecol. Environ. Res. 2019, 17, 6515-6533. [CrossRef]

85. Liu, T.-W.; Fu, B.; Niu, L.; Chen, J.; Wang, W.-H.; He, J.-X.; Pei, Z.-M.; Zheng, H.-L. Comparative proteomic analysis of proteins in response to simulated acid rain in arabidopsis. J. Proteome Res. 2011, 10, 2579-2589. [CrossRef] [PubMed]

86. Du, X.; Wang, G.; Ji, J.; Shi, L.; Guan, C.; Jin, C. Comparative transcriptome analysis of transcription factors in different maize varieties under salt stress conditions. Plant. Growth Regul. 2017, 81, 183-195. [CrossRef]

87. Peng, Z.; He, S.; Gong, W.; Sun, J.; Pan, Z.; Xu, F.; Lu, Y.; Du, X. Comprehensive analysis of differentially expressed genes and transcriptional regulation induced by salt stress in two contrasting cotton genotypes. BMC Genom. 2014, 15, 760. [CrossRef]

88. Feller, A.; Machemer, K.; Braun, E.L.; Grotewold, E. Evolutionary and comparative analysis of myb and bhlh plant transcription factors. Plant. J. 2011, 66, 94-116. [CrossRef] [PubMed]

89. Golldack, D.; Lüking, I.; Yang, O. Plant tolerance to drought and salinity: Stress regulating transcription factors and their functional significance in the cellular transcriptional network. Plant. Cell Rep. 2011, 30, 1383-1391. [CrossRef]

90. Mizoi, J.; Shinozaki, K.; Yamaguchi-Shinozaki, K. Ap2/erf family transcription factors in plant abiotic stress responses. BBA Gene Regul. Mech. 2012, 1819, 86-96. [CrossRef] [PubMed]

91. Li, P.; Song, A.; Li, Z.; Fan, F.; Liang, Y. Silicon ameliorates manganese toxicity by regulating both physiological processes and expression of genes associated with photosynthesis in rice (Oryza sativa L.). Plant. Soil 2015, 397, 289-301. [CrossRef]

92. Liang, Y.; Hua, H.; Zhu, Y.G.; Zhang, J.; Cheng, C.; Römheld, V. Importance of plant species and external silicon concentration to active silicon uptake and transport. New Phytol. 2006, 172, 63-72. [CrossRef]

93. Detmann, K.C.; Araújo, W.L.; Martins, S.C.; Sanglard, L.M.; Reis, J.V.; Detmann, E.; Rodrigues, F.Á.; Nunes-Nesi, A.; Fernie, A.R.; DaMatta, F.M. Silicon nutrition increases grain yield, which, in turn, exerts a feed-forward stimulation of photosynthetic rates via enhanced mesophyll conductance and alters primary metabolism in rice. New Phytol. 2012, 196, 752-762. [CrossRef]

94. Cooke, J.; Leishman, M.R. Consistent alleviation of abiotic stress with silicon addition: A meta-analysis. Funct. Ecol. 2016, 30, 1340-1357. [CrossRef]

95. Guntzer, F.; Keller, C.; Meunier, J.-D. Benefits of plant silicon for crops: A review. Agron. Sustain. Dev. 2012, 32, 201-213. [CrossRef]

96. Mateos-Naranjo, E.; Andrades-Moreno, L.; Davy, A.J. Silicon alleviates deleterious effects of high salinity on the halophytic grass Spartina densiflora. Plant. Physiol. Biochem. 2013, 63, 115-121. [CrossRef]

97. Sahebi, M.; Hanafi, M.M.; Siti Nor Akmar, A.; Rafii, M.Y.; Azizi, P.; Tengoua, F.; Nurul Mayzaitul Azwa, J.; Shabanimofrad, M. Importance of silicon and mechanisms of biosilica formation in plants. BioMed Res. Int. 2015, 2015. [CrossRef]

98. Song, A.; Li, P.; Fan, F.; Li, Z.; Liang, Y. The effect of silicon on photosynthesis and expression of its relevant genes in rice (Oryza sativa L.) under high-zinc stress. PLoS ONE 2014, 9, e113782. [CrossRef]

99. Velikova, V.; Tsonev, T.; Yordanov, I. Light and co2 responses of photosynthesis and chlorophyll fluorescence characteristics in bean plants after simulated acid rain. Physiol. Plant. 1999, 107, 77-83. [CrossRef]

100. Zhang, Y.; Yu, S.; Gong, H.-j.; Zhao, H.-1.; Li, H.-1.; Hu, Y.-h.; Wang, Y.-c. Beneficial effects of silicon on photosynthesis of tomato seedlings under water stress. J. Integr. Agr. 2018, 17, 2151-2159. [CrossRef]

101. Fan, X.-Y.; Lin, W.-P.; Rui, L.; Jiang, N.-H.; Cai, K.-Z. Physiological response and phenolic metabolism in tomato (Solanum lycopersicum) mediated by silicon under Ralstonia solanacearum infection. J. Integr. Agr. 2018, 17, 2160-2171. [CrossRef]

102. Silva, I.T.; Rodrigues, F.Á.; Oliveira, J.R.; Pereira, S.C.; Andrade, C.C.L.; Silveira, P.R.; Conceição, M.M. Wheat resistance to bacterial leaf streak mediated by silicon. J. Phytopathol. 2010, 158, 253-262. [CrossRef] 
103. Anjum, N.A.; Ahmad, I.; Mohmood, I.; Pacheco, M.; Duarte, A.C.; Pereira, E.; Umar, S.; Ahmad, A.; Khan, N.A.; Iqbal, M. Modulation of glutathione and its related enzymes in plants' responses to toxic metals and metalloids-A review. Environ. Exp. Bot. 2012, 75, 307-324. [CrossRef]

104. Hasan, M.K.; Liu, C.; Wang, F.; Ahammed, G.J.; Zhou, J.; Xu, M.-X.; Yu, J.-Q.; Xia, X.-J. Glutathione-mediated regulation of nitric oxide, s-nitrosothiol and redox homeostasis confers cadmium tolerance by inducing transcription factors and stress response genes in tomato. Chemosphere 2016, 161, 536-545. [CrossRef]

105. Teh, C.Y.; Mahmood, M.; Shaharuddin, N.A.; Ho, C.L. In vitro rice shoot apices as simple model to study the effect of nacl and the potential of exogenous proline and glutathione in mitigating salinity stress. Plant Growth Regul. 2015, 75, 771-781. [CrossRef]

106. Xalxo, R.; Sahu, K. Acid rain-induced oxidative stress regulated metabolic interventions and their amelioration mechanisms in plants. Biologia 2017, 72, 1387-1393. [CrossRef]

107. Zhang, Y.; Yao, Q.; Shi, Y.; Li, X.; Hou, L.; Xing, G.; Ahammed, G.J. Elevated co2 improves antioxidant capacity, ion homeostasis, and polyamine metabolism in tomato seedlings under ca (no3) 2-induced salt stress. Sci. Hortic. 2020, 273, 109644. [CrossRef]

108. Arnao, M.B.; Hernández-Ruiz, J. Functions of melatonin in plants: A review. J. Pineal Res. 2015, 59, 133-150. [CrossRef] [PubMed]

109. Debnath, B.; Islam, W.; Li, M.; Sun, Y.; Lu, X.; Mitra, S.; Hussain, M.; Liu, S.; Qiu, D. Melatonin mediates enhancement of stress tolerance in plants. Int. J. Mol. Sci. 2019, 20, 1040. [CrossRef]

110. Erland, L.A.; Murch, S.J.; Reiter, R.J.; Saxena, P.K. A new balancing act: The many roles of melatonin and serotonin in plant growth and development. Plant. Signal. Behav. 2015, 10, e1096469. [CrossRef]

111. Cui, G.; Zhao, X.; Liu, S.; Sun, F.; Zhang, C.; Xi, Y. Beneficial effects of melatonin in overcoming drought stress in wheat seedlings. Plant. Physiol. Biochem. 2017, 118, 138-149. [CrossRef]

112. Li, H.; Chang, J.; Chen, H.; Wang, Z.; Gu, X.; Wei, C.; Zhang, Y.; Ma, J.; Yang, J.; Zhang, X. Exogenous melatonin confers salt stress tolerance to watermelon by improving photosynthesis and redox homeostasis. Front. Plant. Sci. 2017, 8, 295. [CrossRef]

113. Ye, J.; Wang, S.; Deng, X.; Yin, L.; Xiong, B.; Wang, X. Melatonin increased maize (Zea mays L.) seedling drought tolerance by alleviating drought-induced photosynthetic inhibition and oxidative damage. Acta Physiol. Plant. 2016, 38, 48. [CrossRef]

114. Wang, L.; Liu, J.; Wang, W.; Sun, Y. Exogenous melatonin improves growth and photosynthetic capacity of cucumber under salinity-induced stress. Photosynthetica 2016, 54, 19-27. [CrossRef]

115. Gong, X.; Shi, S.; Dou, F.; Song, Y.; Ma, F. Exogenous melatonin alleviates alkaline stress in malus hupehensis rehd. By regulating the biosynthesis of polyamines. Molecules 2017, 22, 1542. [CrossRef] [PubMed]

116. Chen, Y.E.; Mao, J.J.; Sun, L.Q.; Huang, B.; Ding, C.B.; Gu, Y.; Liao, J.Q.; Hu, C.; Zhang, Z.W.; Yuan, S. Exogenous melatonin enhances salt stress tolerance in maize seedlings by improving antioxidant and photosynthetic capacity. Physiol. Plant. 2018, 164, 349-363. [CrossRef]

117. Gao, W.; Zhang, Y.; Feng, Z.; Bai, Q.; He, J.; Wang, Y. Effects of melatonin on antioxidant capacity in naked oat seedlings under drought stress. Molecules 2018, 23, 1580. [CrossRef]

118. Liang, D.; Gao, F.; Ni, Z.; Lin, L.; Deng, Q.; Tang, Y.; Wang, X.; Luo, X.; Xia, H. Melatonin improves heat tolerance in kiwifruit seedlings through promoting antioxidant enzymatic activity and glutathione s-transferase transcription. Molecules 2018, $23,584$. [CrossRef]

119. Debnath, B.; Hussain, M.; Li, M.; Lu, X.; Sun, Y.; Qiu, D. Exogenous melatonin improves fruit quality features, health promoting antioxidant compounds and yield traits in tomato fruits under acid rain stress. Molecules 2018, 23, 1868. [CrossRef]

120. Duan, L.; Yu, Q.; Zhang, Q.; Wang, Z.; Pan, Y.; Larssen, T.; Tang, J.; Mulder, J. Acid deposition in asia: Emissions, deposition, and ecosystem effects. Atmos. Environ. 2016, 146, 55-69. [CrossRef]

121. Keutgen, A.J.; Pawelzik, E. Modifications of strawberry fruit antioxidant pools and fruit quality under nacl stress. J. Agr. Food Chem. 2007, 55, 4066-4072. [CrossRef]

122. Borghesi, E.; González-Miret, M.L.; Escudero-Gilete, M.L.; Malorgio, F.; Heredia, F.J.; Meléndez-Martínez, A.J. Effects of salinity stress on carotenoids, anthocyanins, and color of diverse tomato genotypes. J. Agr. Food Chem. 2011, 59, 11676-11682. [CrossRef]

123. Saleem, A.; Ashraf, M.; Akram, N.; Al-Qurainy, F. Salinity-induced changes in key anti-oxidant enzyme activities and in the levels of some anti-oxidants, osmo-protectants, inorganic ions, and chlorophyll pigments in okra fruit (Abelmoschus esculentus L.). J. Hortic. Sci. Biotech. 2012, 87, 271-277. [CrossRef]

124. Zushi, K.; Ono, M.; Matsuzoe, N. Light intensity modulates antioxidant systems in salt-stressed tomato (Solanum lycopersicum L. Cv. Micro-tom) fruits. Sci. Hortic. 2014, 165, 384-391. [CrossRef]

125. Sun, Q.; Zhang, N.; Wang, J.; Zhang, H.; Li, D.; Shi, J.; Li, R.; Weeda, S.; Zhao, B.; Ren, S. Melatonin promotes ripening and improves quality of tomato fruit during postharvest life. J. Exp. Bot. 2014, 66, 657-668. [CrossRef] [PubMed]

126. Galano, A.; Tan, D.X.; Reiter, R.J. Melatonin as a natural ally against oxidative stress: A physicochemical examination. J. Pineal Res. 2011, 51, 1-16. [CrossRef]

127. Liu, T.; Chen, J.A.; Wang, W.; Simon, M.; Wu, F.; Hu, W.; Chen, J.B.; Zheng, H. A combined proteomic and transcriptomic analysis on sulfur metabolism pathways of Arabidopsis thaliana under simulated acid rain. PLoS ONE 2014, 9, e90120. [CrossRef] [PubMed]

128. Martinez, V.; Nieves-Cordones, M.; Lopez-Delacalle, M.; Rodenas, R.; Mestre, T.C.; Garcia-Sanchez, F.; Rubio, F.; Nortes, P.A.; Mittler, R.; Rivero, R.M. Tolerance to stress combination in tomato plants: New insights in the protective role of melatonin. Molecules 2018, 23, 535. [CrossRef] [PubMed] 
129. Zhang, N.; Sun, Q.; Li, H.; Li, X.; Cao, Y.; Zhang, H.; Li, S.; Zhang, L.; Qi, Y.; Ren, S. Melatonin improved anthocyanin accumulation by regulating gene expressions and resulted in high reactive oxygen species scavenging capacity in cabbage. Front. Plant Sci. 2016, 7, 197. [CrossRef] [PubMed]

130. Shi, H.; Tan, D.X.; Reiter, R.J.; Ye, T.; Yang, F.; Chan, Z. Melatonin induces class a1 heat-shock factors (hsfa 1s) and their possible involvement of thermotolerance in arabidopsis. J. Pineal Res. 2015, 58, 335-342. [CrossRef] [PubMed]

131. Liang, C.; Zheng, G.; Li, W.; Wang, Y.; Hu, B.; Wang, H.; Wu, H.; Qian, Y.; Zhu, X.G.; Tan, D.X. Melatonin delays leaf senescence and enhances salt stress tolerance in rice. J. Pineal Res. 2015, 59, 91-101. [CrossRef]

132. Shi, H.; Jiang, C.; Ye, T.; Tan, D.-X.; Reiter, R.J.; Zhang, H.; Liu, R.; Chan, Z. Comparative physiological, metabolomic, and transcriptomic analyses reveal mechanisms of improved abiotic stress resistance in bermudagrass (Cynodon dactylon L. Pers.) by exogenous melatonin. J. Exp. Bot. 2014, 66, 681-694. [CrossRef]

133. Lee, H.J.; Back, K. 2-hydroxymelatonin promotes the resistance of rice plant to multiple simultaneous abiotic stresses (combined cold and drought). J. Pineal Res. 2016, 61, 303-316. [CrossRef] 